\title{
2. Demonstrating the Stone-Age in Dutch New Guinea
}

\author{
Danilyn Rutherford
}

What is a colonial officer to do? When the radio he has been waiting for to begin his expedition into uncharted land arrives only to break the first time it is used? When the coolies he has recruited from a nearby coastal settlement announce they are going on strike? When his superiors suddenly decide he should head for an entirely different region than the one he was planning for - a region for which he has no maps and has read no reports? When the scientist along for the expedition, who has never been to this island, changes the route under the mistaken assumption that it is harder to travel by water than to walk? When it becomes apparent that the erstwhile commander of the expedition has little control over its components - and little reason to think that the natives he meets will be impressed by his government's supposed sovereignty over their land?

Police commissioner Jan van Eechoud faced all these challenges, and pondered them grimly, while waiting at Pioneer Bivak to begin his third expedition up the Mamberamo River into the Dutch New Guinea highlands, in the hinterland of what was then the Netherlands Indies. What's a colonial officer to do? Here's what van Eechoud did: he built a machine. To pass the time and make himself useful, van Eechoud gathered ethnological data from members of the surrounding tribes, inviting the Papuans into his tent to be interviewed in a mixture of Malay and the little he had picked up of the local tongue. With a crowd of Papuans watching, the individual providing information sat on a petroleum drum, answering questions on kinship, religion and politics in exchange for tobacco and food. Some 'lecturers' as van Eechoud called them, enjoyed the refreshments so much that they rambled on and on. Afraid of offending his informants, he used 'indirect means to end a discussion' (1953: 181). At first, he tricked the entire group into following him outside, then jumped back into the tent and locked the door. Then he came up with a more ingenious solution:

The petroleum drum was placed on a plank, so that it was separated from the ground. Attached to the plank was an insulated wire that ran in a wide arc along the wall then outside to where it was attached to the spark plug of a Delco motor [DR: a battery-operated starter motor, presumably from one of the motor boats used by the expedition]. When I wanted a lecturer to go away, without interrupting the discussion or looking up I said under my breath to Dr. Koppeschaar, 'Doc, run it!' After a minute, the doctor vanished outside and pressed the Delco 
motor's start knob. All of a sudden, the lecturer sat up with a grimace on his face, convulsively waving his arms and legs until he had a chance to get off. After that, he stood there, looking around, asking himself what had happened to him. (van Eechoud 1953: 181)

They never grasped the connection between the drum, wire, and Delco motor, but when the trick had been played several times, they very well got wind of one coincidence: if someone was invited to sit down, he squinted at the drum, looked at me suspiciously, and asked anxiously, 'Doc, run it?' After my comforting declaration that there would be no 'Doc, run it' he would take a seat and light up a cigarette. (van Eechoud 1953: 181)

Unable to command the Stone-Age Papuans directly, van Eechoud managed to dominate them through a proxy. He bent them to his will through the words by which he commanded a modern machine.

Van Eechoud didn't stage a technology demonstration in the typical way, which would have involved producing what Erving Goffman called a 'theatrical frame' by using conventional signals (such as a sideshow barker's 'Step right up!') to attract an audience and focus its attention on the action about to unfold (1986 [1974]: 124-155). Yet this scene contains many of the ingredients that will detain us in the pages that follow: a machine unfamiliar to local people produced an action that elicited fear, surprise, amusement and curiosity. And, in the hopeful imaginations of colonial impresarios, these performances elicited respect for Dutch visitors and the regimes they represent.

In this essay, which forms part of a larger project, I focus on technology demonstrations staged in the Wisselmeren region of Dutch New Guinea between 1936 and 1953. This part of present-day Papua launched the careers of influential officials, including van Eechoud, who promoted the policy that led to Dutch New Guinea's continued colonisation following World War II (see Derix 1987; Drooglever 2005). Van Eechoud and his colleagues led expeditions into the territory's interior in the 1930s. Daily life on these journeys blurred the boundaries between colonisers and colonised, not to mention New Guinea's erstwhile rulers and their tools. The technological performances I explore in this paper intervene to redraw a sharp line. At the same time, they staged a meeting between the Stone-Age and modernity, they opened a gulf that kept these times apart.

In making this argument, I draw on snapshots from three authors: Dr H.J.T. Bijlmer, who wrote a book on his 1936 journey to the Wisselmeren (n.d.); Jan van Eechoud, who wrote reports and a memoir on his experiences in the same region (1938, 1953; see also de Bruijn 1939a, 1939b, 1939c, 1941); and Dr K.W.J. Boelen's memoir depicting a later moment of colonial state building, when the 
Dutch returned to the Wissel Lakes after the war (1955; see also Meijer Ranneft 1952; van Emmerik 1953). These snapshots enable me to track the progress of state building in the highlands as the Dutch consolidated their hold on the region and established an apparatus with a growing number of the elements associated with modern rule. They also offer glimpses of Papuan perspectives on this changing scene. Over the period I cover, the Wisselmeren's inhabitants, and Papuans elsewhere in Dutch New Guinea, became increasingly nimble in appropriating the authority and status they came to associate with motors, gramophones, magnets and other modern instruments. At the same time, they grappled with and sometimes reproduced the view that made Stone-Age primitives out of people who used stone axes and knives.

The authors I consider didn't invent the idea of the Stone-Age; that was the work of the Danish curator, Christian Jürgensen Thomsen, who in 1816 came up with the idea of dividing artifacts among galleries representing eras defined by the materials used for tools. ${ }^{1}$ Nor did they invent the idea that present-day 'non-metallic savages' could serve as proxies for Europeans' own Stone-Age ancestors. For that, we can thank Sir John Lubbock, who wrote what some call the most influential archaeological textbook of the 19th century, Pre-Historic Times (1865). ${ }^{2}$ They weren't even the first to import Lubbock's proposition to Dutch New Guinea. Earlier in the 20th century, when English and Dutch explorers ventured into the territory's mountainous interior in what Ballard, Vink, and Ploeg (2002) call 'the race to the snows', the notion that the people they encountered were throwbacks to an earlier stage in human development was ready to hand. The record of one such expedition, A.F. Wollaston's Pygmies and Papuans: The Stone Age Today in Dutch New Guinea (1912), was a popular bestseller in its day. What these authors did to this conceit was to give it political purchase and staying power in the waning years of the Netherlands Indies, when Dutch colonials and Indo-European activists hatched the first plans to administer New Guinea separately from the rest of the colony (see Rutherford 2012). They helped to turn the Papuans' positioning in this particular version of what Michel-Rolph Trouillot (1991) called 'the savage slot' into an excuse for Dutch New Guinea's prolonged colonisation and the denial of Papuans' political rights.

But that's skipping to the end of the story. The first step is to scrutinise how the Stone-Age became palpable for these adventurers. To grasp how technology

\footnotetext{
1 Thomsen, who organised what was to become the Danish National Museum on this basis, is credited with inventing stratigraphy, a dating method central to modern archaeological research. See http://en.wikipedia. org/wiki/Three-age_system, accessed 19 February 2013.

2 See http://en.wikipedia.org/wiki/John_Lubbock,_1st_Baron_Avebury.
} 
From 'Stone-Age' to 'Real-Time'

demonstrations helped to consolidate the Stone-Age image of New Guinea, we must approach them as performances - performances that both acted out claims to sovereignty and put it at risk.

\section{Demonstrate, perform, or, how to do things with things}

We have all been there. We're watching television. Steve Jobs stands at a podium introducing the latest Apple product. An enormous screen lights up behind him, and he puts the device through its paces. Or we're at the movies. Hugh Jackman walks onto a stage and steps into a wire cage. Lights flash, the wires shoot off sparks and he disappears, only to reappear at the back of the hall. Demonstrations of technology: they entertain and sometimes dazzle, but they also create the impression of a consolidated kind of agency. Apple's founder both borrowed power from and lent power to the iPad. His technology demonstrations invited shareholders to buy into the premise that the creative power of a man and a brand, not a network of people and previous inventions, found expression in a machine's novel actions. A magician does the same thing when he performs a technological trick. His performance constitutes a massive disavowal of the distributed nature of agency: the networks of people, artifacts, and histories of practice gathered together in every technique (see Heidegger 1977; Hutchins 1995; Stiegler 1998; Riddington 1999; Mauss 2006). 'The Real Transported Man', not the transporter, appears on the marquis in The Prestige: the transporter's agency becomes the magician's own.

These examples reveal the performative nature of technology demonstrations. The philosopher John Austin (1976) defined performatives as phrases, like 'I promise', 'I deny', 'I swear' or 'I declare', that do what they say they are doing in the very act of being said. What Austin called a 'speech act' creates the impression of willful agency, attesting to a speaker's capacity to change the world. In the case of technology demonstrations, people achieve a similar outcome - only not, as Austin puts it, by doing with words but also by doing things with things. In colonial settings, this aspect of technology demonstrations becomes obvious. Greg Dening (1980) writes of the 'shows of force' that 18thand 19th-century ship captains felt compelled to stage in order to control the Marquesan islanders who swarmed onto their decks. To stop the islanders from stealing, the sailors sometimes shot a few. The others learned to flee, and to appreciate the power of firearms, which they soon began acquiring by trading local goods. On the Australian half of New Guinea, 20th-century patrol officers and prospectors sometimes staged brutally direct shows of force, as when some Yonki men attacked Jim Taylor, and his police opened fire, or when Mick 
and Dan Leahy shot a handful of Papuans in a village where they found gold (Gammage 1998: 11, 12). But they also staged technology demonstrations as a way of putting their capacities on display. One sees such a scene at the end of the documentary First Contact, when the Leahy brothers line up some Papuans to show them how a rifle can kill a pig (see e.g. YouTube 2008). ${ }^{3}$

On the Dutch side of the island, the administration avoided open conflict, and there were far fewer killings of either locals or their guests in the encounters that accompanied state building in the interior. Officials like van Eechoud were tasked with establishing peaceful contact with 'our' authority and making the Papuans' behavior more 'predictable', 'according to our concepts' (see Rutherford 2009). Technology demonstrations, especially involving firearms, proved a favourite method for trying to ensure that the Papuans would recognise 'our authority' as authority - especially when the guns were wielded by bedraggled and hungry hikers who scarcely seemed capable of caring for themselves. Repeatedly seeing a rifle or gramophone in action would make Papuans better able to predict the behavior of modern weapons and devices. Their own behavior would become more predictable as a result. Somehow, the shooting of pigs - and, as we will see, the playing of gramophones - would constitute a Dutch ' $\mathrm{I}$ ' and a Papuan 'you' - the agent and patient of colonial sovereignty. The Papuans would come to recognise technological supremacy as an attribute of Dutch personhood; something that these 'white men' naturally had. In insisting on the range of human and non-human agents involved in every act of thinking, Edwin Hutchins has criticised the idea that primitive technologies are the product of primitive minds (1995: 355). The technology demonstrations staged by Dutch officials had the effect of perpetuating this mistake. Van Eechoud could not always control the trekking machine; he could rarely tell the primitives what to do. Technology demonstrations enabled him to persuade himself and others, however fleetingly, that machines were the measure of men.

Another way to put this is that Dutch officials staged these performances in order to cultivate particular inferences among the Papuans (see Hume 1988

\footnotetext{
3 This is not to say rifle demonstrations always worked to instill respect for Australian authority. Gammage quotes Patrol Officer Jim Taylor writing of his earliest patrols in the eastern New Guinea highlands, where, in the company of the Leahy brothers, who first discovered gold in the region, he explored the Baiyer and Jimi valleys and climbed Mt Hagen in 1932. One way home, the men faced frequent attacks and found the 'attitude of the natives ... entirely different from that on our first trip through':
}

Then they imagined us gods or spirits but on reflection they realized their mistake apparently and so a revulsion of feeling took place ... Our peaceful behaviour they regarded as being due to us not being warriors - and to an absence of weapons. Rifles they imagined were sticks and though they saw them shoot through trees and kill pigs they still could not connect them with their concept of war. Day after day we encountered large numbers of hostile or contemptuous people who shouted insults at us and howled with derisive laughter when told to desist. They appeared to think that they had us in their power ... One fellow actually brought rope to tie up his share of the loot.

See Gammage 1998: 13. 
[1748]; Rutherford 2009). Technology demonstrations invited Papuan audience members to trace an effect to a cause, a cause residing in the body of a human actor and, by extension, others like him. The concept of personal or group identity arguably results from just such acts of inference (see Hume 1988 [1748]: 50-66). People do things, we presume, because they are the sorts of people prone to behaving in just this way. Speech acts offer a particularly powerful way to link an identity and an action. The power of a performative resides in a speaker's ability to refer to the fact that he or she is speaking (see Lee 1997; see also Rutherford 2012). The relationship between our words and the world may be arbitrary, and our statements may be erroneous. But when I say, 'I am saying', I can't help but speak the truth. ${ }^{4}$ This utterance enables me to believe, if only for an instant, that the power to speak belongs to the speaker alone, instead of stemming from multiple sources: from the qualities of sound waves to the evolutionary processes that gave us our tongues, ears and brains to the habits and expectations we have acquired from living in settings where people use signs in particular ways. What Austin (1976) calls speech acts are technology demonstrations, to the extent that language is a tool, a prosthetic device made by humans that in turn makes humans what they are (see Mumford 1967; Stiegler 1998). Rifle demonstrations and wedding vows both focus attention on the fiction of a cause: the officer who pulls the trigger, the bride who says 'I do'.



Figure 2.1. Expedition member S. van der Groot demonstrates the workings of a magnifying glass to a group of Ekari Papuans, 1936.

Source: Tropenmuseum Collection 10032903, http://papuacollectie.ab-c.nl.

4 What's more, the person ' $\mathrm{I}$ ' become in articulating this phrase takes on an unassailable-seeming reality as the agent of this speech act. The pronoun itself already refers to the event of its utterance: ' $\mathrm{I}$ ' is defined as the individual uttering 'I' (See Benveniste 1971). 
Paying heed to this function of technology demonstrations not only helps us better understand their appeal for colonial officials. It also helps us understand how these performances could run astray. Speech acts only work because they are conventional, which means they are repeatable - or 'iterable', to use the philosopher Jacques Derrida's (1982, 1986) term - and detachable from any particular context of use. 'I promise' may lose some of its 'felicity' - its 'happy' effect - when uttered in jest or onstage. This question of iterability bears in two ways on the efficacy of the technology demonstrations I consider. On the one hand, this was not a setting where one could presume that what one took to be conventions were, in fact, conventions: colonial officials had to repeat their experiments, as it were, engineering experiences that created expectations in order for a demonstration to have its desired effect. On the other hand, the iterability of technology demonstrations gave Papuans a chance to engage in their own experiments, which sometimes had subversive effects. Suffice to say that local notions of personhood, agency and authority loomed large in their performances, in ways I can only gesture towards here. ${ }^{5}$ To get a sense of the powers and dangers of these colonial performances, let's turn to our first snapshot, which portrays a performance staged by Dr H.J.T. Bijlmer, who had a particularly keen desire to use modern technology to reveal the nature of primitive selves.

\section{Snapshot 1: The circus comes to town}

Dr. H.J.T. Bijlmer was a medical doctor and an 'anthropologist', a term that in his day referred to a specialist in the study of the racial types that made up the human species. He arrived in the southern part of the Wisselmeren in 1935-36 at the end of an expedition to investigate the so-called Tapiro Pygmies, a smallstatured group of Papuans first encountered by Europeans in 1910. ${ }^{6}$ He reached

5 Some of the Papuans involved might well have had little trouble understanding what Austin was talking about when he described how performatives work. During the early 1950s, Leopold Pospisil (1963) interviewed a number of philosophically inclined Kapauku in the 'uncontacted' Kamu Valley. They explained that persons were composed of two parts: bodies and souls. 'To live' was ami-tou, 'to sleep, referring to the separate existence of the soul, and to stay in place, referring to the material existence of the body.' 'My body stays in place, my soul dreams, and I live,' one man explained (Pospisil 1963: 87). For the Kapauku, Pospisil elaborated, " I" means consciousness; it means the thinking process is the cooperative effort of the body and soul' (ibid.). This model of the person, which valorised the unified action of an uttered word or enacted gesture and a body staged in space, may well account for the appeal of technology demonstrations and the eagerness of Kapauku to repeat them.

6 Bjilmer undertook this trip at the behest of the Maatschappij ter Bevordering van het Natuurkundig Onderzoek der Nederlands Kolonien (Corporation for the Advance of Natural Scientific Research in the Dutch Colonies) and the support of then Governor General B.C. de Jonge and his boss, the Minister of Colonies and New Guinea enthusiast, Dr H. Colijn (see Biljmer n.d.). Twenty companions came along, including a local government official, Civiel Gezaghebber S. van der Groot, and the Catholic priest, Father Tillemans, whom Bijlmer had met in 1931, when he served as medical officer on a British expedition to the top of Mt Carstens (ibid; see also Ballard et al. 2002). (The British expedition had passed through the Tapiro pygmies' homeland, and Bijlmer and Tillemans met individuals who still remembered them - and, no doubt, their loot, which took the form of metal knives, axes, shells, mirrors and beads [Bijlmer n.d.: 49].) 
the Wisselmeren by way of Mimika, the coastal region that was the entryway to the region for van Eechoud as well. Biljmer was no novice; during an even earlier expedition in 1920, Bijlmer had visited the Swart Valley, the first densely populated area of the highlands that Dutch explorers reached by foot. Bijlmer called his book on the journey To the Ends of the Earth, and, as this title makes clear, New Guinea had lost none of its charm for Bijlmer in the intervening years. Framed as fodder for the popular imagination, Biljmer's account of his adventure shows how technology demonstrations gave Dutch travellers a sense of superiority at moments when their mastery seemed in doubt.

For Bijlmer, stone tools and Stone-Age selves went together in a way that made New Guinea's present a mirror onto the Netherlands' past. In the Swart Valley, Bijlmer found himself in

...a world from past ages! Because weaving and pottery appeared unknown, and people felled the forest and cut planks with stone axes! Not a scrap of metal was to be seen; the Stone-Age, sunk deep in the mists of prehistory in Europe, was here in full bloom ... The extant stone axe is the sign that this folk still pass their days untouched by civilization. That is why studying them is so extraordinarily important. (Bijlmer n.d.: 17)

For Bijlmer, the continued use of stone axes in the Swart Valley and elsewhere was a sign of the mountain Papuans' isolation: this was a land forgotten by time, a land that 'brought nothing' from the civilised world. This characterisation is, of course, debatable. Given the lengthy trade routes that crossed the highlands, its inhabitants' multilingualism, and the delight so many of them took in travelling and trading, it seems unlikely that highlands Papuans waited passively for imports to arrive (see e.g. Pospisil 1963; Haenen 1992; Timmer 2000). Yet it is illuminating of the fantasy that Bijlmer experienced technology demonstrations as affirming - a fantasy in which the Dutch explorer reached across the eons to touch the lives of the mountain Papuans and was exhilarated to discover that these living ancestors were just like him.

Bijlmer's experiences in the Wisselmeren fed this fantasy. After taking biometric measurements among the Tapiro, Bijlmer returned to the coast and made his way into the region, where the first community he reached was in the densely populated Pogi Valley. The inhabitants were Kapauku, members of the ethnolinguistic group that made up the lion's share of the population in the vicinity of the lakes. While the coolies made camp, Bjilmer and the Dutch officers sat among curious onlookers; gradually a dozen men gathered. With the delicacy of a nature lover coaxing a wild animal, Bijlmer managed to lure several women and a child close enough to put a string of beads around the little girl's neck. 


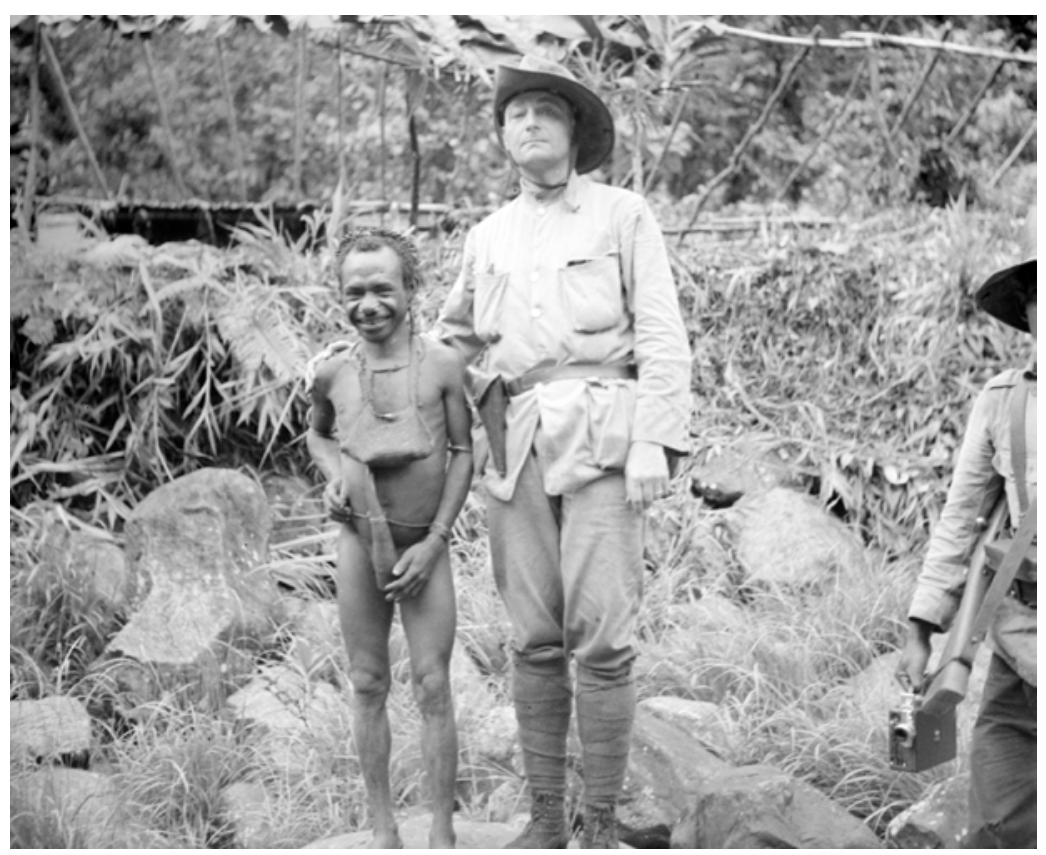

Figure 2.2. Portrait of H.J.T. Bijlmer with an Ekari Papuan, 1936.

Source: Tropenmuseum Collection 10032847, http://papuacollectie.ab-c.nl.

But the real excitement came after a larger crowd had gathered.

We decided to do a demonstration with the gramophone. We had brought this instrument along in the first place to observe the effect it would have on primitives, but I will happily admit I also got much pleasure out of it.

A score of men pressed up close to the table; the six women sat at a safer distance.

We chose Sarie Marijs, sung by a deep male voice, as the first record. Upon first hearing the music, the listeners rubbed their ears in wonder, but when the male voice resonated their amazement knew no bounds. Ten faces - the women had taken flight - stared in dumb amazement at the fantastic instrument ... and now these were human faces in full form! They may actually have been primitive, somewhat foolish faces, but now they exuded spirit and effervescent life. Each reacted in his manner. There appeared tense attention on the face of one; straightforward wonder on that of another; paranoid fear, cheerful joy, dumb ecstasy, an investigative gaze on the rest! There were those who, without showing any fear, took up the matter seriously and sank into a reverie; there 
were others who, after they overcame their hesitation, examined the device from all angles and didn't recoil from a bold investigation. Next to peaceful thinkers, one noticed clever investigators in the making ... No, it's not like we found anything different than what is to be expected by every student of humanity. But such an experience at what one might say is the source is always worth mentioning. As if in a fantasy, we discovered in the end ourselves: we are here within our own prehistory! (Bijlmer n.d.: 137-138)

Our own prehistoric circus: 'The Papuans' stance towards us was scarcely different from that of a spectacle hungry crowd at a fairground back home' (ibid.). The demonstration brought familiar passions into focus by wiping the 'foolishness' off the villagers' primitive faces. Bijlmer took the most pleasure in the 'clever scientists' in the making; those who shared Bijlmer's own 'investigative gaze'. That's not to say that the Papuan researchers were capable of penetrating the mystery. They gave up when Bijlmer played a second record, which featured a female singer and destroyed their theory that Bijlmer or one of his colleagues was throwing his voice.

Bijlmer had this happy scene to remember during episodes that called his competence into doubt. In another passage, Bijlmer described huddling, wet and cold, on a rugged trail, waiting for his coolies to build a shelter. His Kapauku guides looked on with pity and scorn, but there was no reason to worry about their reactions. The Dutch could afford to be 'friendly' with the Papuans, Bjilmer noted, given that 'the respect that our arrival, our appearance, and all our doings inspired was so great' (n.d. 157). This is a fantasy of superiority, but, if we follow Rupert Stasch (2009), then we can see that it tamed otherness as much as it created it. The Stone-Age Papuan did not appear as our father, someone who shared the current moment, but whose death the Dutch would survive. Rather he appeared as a younger version of 'ourselves'; someone whom, outside of science fiction, the Dutch could never meet. A temporal wall divided the Dutch from the Papuans. A trick with a record player was all it took.

But the gramophone was not the only machine Bijlmer relied upon to affirm his superiority. The expedition's leaders might have been friendly, but they weren't foolish: they insisted that the party should travel with armed guards. Van Eechoud, who came to the Wisselmeren to govern, not measure heads, could not be quite as confident in the outcome of these performances. Let's turn now to our second snapshot and the multiple ways a rifle could misfire.

\section{Snapshot 2: Performing sovereignty}

Police Commissioner Jan van Eechoud passed through the same region where Bijlmer had conducted measurements on his way with a long line of coolies and 
police agents to establish a post in Enarotali, a lakeside village in the heart of the Wisselmeren. Elsewhere I have described the logistical difficulties van Eechoud faced in carrying out this mission (Rutherford 2009). When it came to recruiting the support of local Papuans, challenges raised their head right from the start. Van Eechould wasn't sure that the first group of Kapaukus he met would be as friendly as they had been with earlier visitors. So he decided to make a show of force 'to get rid of any unpleasant ideas that might have found their way into their heads' (1953: 103).

Behind a twenty-centimeter tree, an empty trekking drum was set. Five meters in front of the tree, I positioned myself with a carbine. Through gestures and by making noise, I tried to make it clear that the tree as well as the can would be bored through with a loud report. Full of tension, the group watched. I aimed, shot, and looked triumphantly to see the effect on their faces - but there were no more faces. With great leaps, some of the group had vanished into the forest, while others raced at full sped to the other side of the garden running, or so they thought, for their lives.

If another shot had been fired, then the poor devils in their panic would have climbed over Mt Carsten. But we began to call reassuringly - at least it seemed to us reassuringly. Meanwhile, at least a half an hour went by before a couple of them dared to return, wavering and reluctant. Fear was again in their eyes when they looked at either me or the carbine. (van Eechoud 1953: 103)

Van Eechoud began the demonstration with a prophecy: gestures and noise meant to mimic the shooting of the carbine. He used a drum and a tree as targets; later he used pigs, which provided him with an even better way of demonstrating his weapons' - and his government's - power. The demonstration displayed the sovereign's grip on what Agamben called the 'mere fact of living', which is what pigs and, in a different way, trees share with people. But sovereignty needs more than 'bare life'; it needs an audience as well (Rutherford 2012). The Kapauku had to fear van Eechoud enough to remove any 'unpleasant ideas' from their heads. But they had to trust him enough to feed him, given his difficulties with the supply line. To balance these imperatives, van Eechoud had to display the state's capacity for violence without scaring the Papuans off.

As it turned out, firearm demonstrations did help to sustain van Eechoud's security and food supply. But not for the reasons he presumed they would. When news of van Eechoud's expedition reached Timiela, the inhabitants of this village brought the colonial officer a piglet and asked him to shoot it (van Eechoud 1953: 114). Like the audience at a tightrope act, the Kapauku found these 'executions' unnerving; and yet they enjoyed the show. Van Eechoud's successor, Jan Victor 
de Bruijn, gained enough of a sense of local life to understand that the appeal of these performances: pigs were publicly slaughtered at the elaborate pig feasts where Kapauku gathered to dance and trade shells for pork (see Pospisil 1963: 270). The shooting of a pig with a revolver intended to scare hostile villagers also served as a familiar way of making 'friends' (Van Eechoud 1953: 138).

These Dutch travelers were able to assure themselves of the 'deep respect' and even 'affection' - that 'our arrival, our appearance, and all our doings' had inspired (Bijlmer n.d.: 178) in the Kapauku. Yet their writings bear witness to what potentially could become disturbing appropriations of the power the Dutch seemed to wield when they played a record or shot a pig. Bijlmer tells of young Kapauku repeating the experiment with the magnet, showing off their own agency to their friends. De Bruijn describes how some villagers chanted 'So! So!' whenever he shot a pig, repeating the expression the colonial officer always uttered when the deed was done (1939a: 80). After the war, when the Dutch re-established a colonial presence in New Guinea, some Kapauku rebelled and lost their lives. But even as Papuans learned more radical ways of appropriating the machinery of state building, they found it increasingly difficult to leave the Stone-Age behind.

\section{Snapshot 3: Our demonstrations, their demonstrations}

Dutch officials returned to Wisselmeren in 1948 to reopen the post in Enarotali. Assigned to head up the health department, the author of our third snapshot, Dr K.J.W. Boelen, arrived several years later with his pregnant wife. Technology demonstrations of a routine sort had become the order of the day: those that made up the work of the growing corps of Kapauku teachers, nurses and clerks. But even as they mastered modern instruments, the Stone-Age stuck to their identities, like glue from a label they couldn't peel off.

Boelen, like other chroniclers of this period, spilled much ink describing typical Kapauku technology: houses, fire starters and net bags, but above all clothes (see also Meijer Ranneft 1952; van Emmerick 1953). He found the attire of new Kapauku police recruits particularly arresting:

The corps follows military order. The Kapauku recruits take part in the force in local clothing, and it is a funny sight to see them, in full gravity, under the command of the Agent First Class, performing drills dressed only in penis gourds. But they quickly get their uniforms, and one can see an impeccably clad help agent, with his wife in her fiber skirt, off to church on a Sunday morning, both fully aware of their importance. (Boelen 1955: 22) 
Boelen goes on to note that the Kapauku agents could prove very helpful as guides or interpreters. They were less adept in the main responsibility of the police force, which was to lead the locals 'to accustom themselves to having a higher authority above them. Instead they remained in the thick of local things, using 'the authority of their uniform' to win their own family disputes' (ibid.). We don't often think of wearing an outfit as demonstrating a technology, but Boelen's remarks are legible in these terms: the uniform becomes a tool the agents turn toward their own ends.

But in making this point, Boelen also points to the mismatch between Papuans and modern technology: the clothing never quite fits these men. In another passage, Boelen describes how the 'old customs ... came again to the surface during tours'.

During rainstorms, one sometimes sees the Kapauku agents putting back on their penis gourds, although they keep the American helmets with the initials 'A.P.' (Algemeen Politie) [DR: General Police] on their heads and their rifles on their shoulders as a sign of their dignity. Also at feasts, the awkward clothing is set aside and the penis gourd takes its place. (Boelen 1955: 22)

From the depths of Papuan identity, Stone-Age tendencies can't help but resurface: you can take the Papuan out of the penis gourd, but you can't take the penis gourd out of the Papuan. When Stone-Age bodies meet modern garments, the effect is both amusing and ephemeral - modernity doesn't sit well, and it is easily cast off. Boelen's memoir partakes of a fantasy that creates a tight bond between the essential traits of Europeans and the capacities of modern equipment. The essential traits of Papuans, by contrast, are at odds with modern technology. Their technological performances are inherently infelicitous: theatrical spoofs rather than serious enactments of an agency that cleaves to an instrument like a hand slipped into a glove. This is a conceit purpose-built for what Homi Bhabha (1994) described as the ambivalence of colonial discourse (see also Spyer 1998). On the one hand, natives had to have the capacity to become like their colonisers for the civilising mission to have meaning. Yet they couldn't actually achieve this goal, or the civilising mission would have to end. ${ }^{7}$

More disturbing appropriations of modern things and ways also preoccupied the small Dutch community. Officials wrote extensively about the rebellion members of the Pakage clan mounted against the Dutch government and its proxies. The violence against persons and property that took place during this conflict merely confirmed the intractability of Stone-Age practices; in all but a

7 As I have suggested, the appeal of New Guinea for the Dutch during this period rested on its primitive character. No matter how civilised, dignified or respectable they appeared, the Stone-Age Papuans would remain primitive beneath the surface for generations to come. 
few regions, the Dutch gave up on stopping local wars. Less easy to put out of mind was Zacheus Pakage, a Kapauku convert sent by American missionaries to Makassar for training (see Giay 1995; see also Boelen 1955: 22-23; van Emmerik 1953: 36-39). ${ }^{8}$ Upon his return in 1950, Pakage insisted on being posted in his own home region, where he used his influence to begin a movement using Christian ritual and doctrine against the colonial regime. ${ }^{9}$ The power of coastal Papuans also became the target of capture. A man and his wife who had lived in Kokonau, a town on the southern coast, unsettled Dutch officials when they returned to the Wisselmeren to open a 'school'. They modeled loincloths, a coastal garment, and demonstrated fire walking, a coastal custom, to prove they had access to supernatural powers (van Emmerik 1953: 36). Here were examples of mimicry gone too far.

And yet, even as the Kapauku learned more and more radical ways of appropriating others' technologies, they also were forced to recognise, and sometimes even internalise, the racial hierarchy on which Dutch self-assurance rested. However subversive they might have seemed, Papuan technology demonstrations could not help but affirm the conceit underlying the StoneAge fantasy. In using the same tricks as the Dutch did to demonstrate their superiority, Kapauku leaders strengthened the opposition that divided modern and Stone-Age bodies and things. This opposition had the potential to poison relationships among Papuans with different histories of colonial contact. Boelen relates the following incident involving his Kapauku houseboy, Marcus.

The wife of a colleague from Biak offered to find a Biak girl. Marcus helped us set up the small room next to the kitchen. We put in a bed and laid an earthen floor. When Jacomina arrived with the Catalina, she was exuberant from her first flight and found everything lovely. Marcus, in a clean, pretty shirt, carried her bag with an aggrieved look. She found him a most amusing boy and spoke to him in rapid Malay, so that he could barely follow her. She nearly choked when she saw her first mountain Papuan walking by in a penis gourd. She found our house pretty, was taken by her room, and asked my wife a hundred things. Marcus deported himself very shyly, but within an hour he found that the women's chatter must come to an end, and it was time for more scientific pursuits. He put his slate under his arm and said firmly, 'Mama, I'm going to school'. This did not impress Jacomina in the least. In Biak, most children start school at the normal age and have already

\footnotetext{
8 This was against the better judgment of I.J.R. Meijer Ranneft, who at the time was the head of government in the Wisselmeren.

9 Zacheus threatened to quit if the missionaries refused. By a gentleman's agreement, the Roman Catholics split the region with the Christian and Missionary Alliance, an American Protestant group. Tigi was officially a Catholic mission field; the missionaries wanted Zacheus to go to Wandai, three days walk to the east.
} 
finished by the time they are twelve. She began to laugh and asked him bluntly: 'Such a big boy already, and you are still going to school? How funny. How old are you, and what grade are you in?' (Boelen 1955: 70)

Marcus 'slinked off' with an offended sniff; 'things were never in order between him and Jacomina'. Note how this coastal Papuan internalised the Dutch view that made Stone-Age tribes out of people who had once used stone tools. Marcus' performance with the books and slate could not make him seem 'civilised' to Jacomina. This technology demonstration's failure justified continued colonisation. The Stone-Age was becoming a prison that was hard to escape.

\section{Conclusion: 'Paper's power'}

A Dutch official sets up a gramophone and turns it on. His finger pulls a trigger and a bullet leaves a barrel, speeding towards a hapless pig. We can trace these events to an endless series of causes: from the supplier who sold these devices, to the government coffers that paid for them, to the experiences that shaped the official's habits and expectations so he could operate these machines. This is not to mention the histories that gave rise to the gramophone and the rifle, which include the moments of memory and anticipation that are inscribed in every technical thing (see Stiegler 1998). All these possibilities are put out of mind as the official sets these machines in motion. Of course, a clever Papuan could well have asked the colonial official, 'Did he himself understand how a gramophone or a rifle works?' No one ever grasps, no one ever masters, the workings of their own minds and bodies, let alone all the other things of which social persons are composed.

Among these things is the technology of writing: the paper, pens, typewriters, filing cabinets, printing presses, archives and libraries that made these officials' stories available to me and through me to you. ${ }^{10}$ 'The Papuan is not conscious that the paper's power lies in the words written on it,' Bijlmer wrote of a Kapauku messenger who loudly announced the instructions he had been given instead of simply handing over the letter (1938: 174). In fact, the messenger was right: paper doesn't speak by itself. Its power lies not merely in the words written upon it, but in how it is handled - how it enters circulation and with what effects. Paper played a central role in fueling the Stone-Age fantasy that continues to dog the people of today's West Papua. The texts I have considered reached a broad Dutch audience. And the effects on West Papua's people were great.

10 On the power of paper to shape colonial encounters like the ones described in this essay, see Mueggler (2011). 


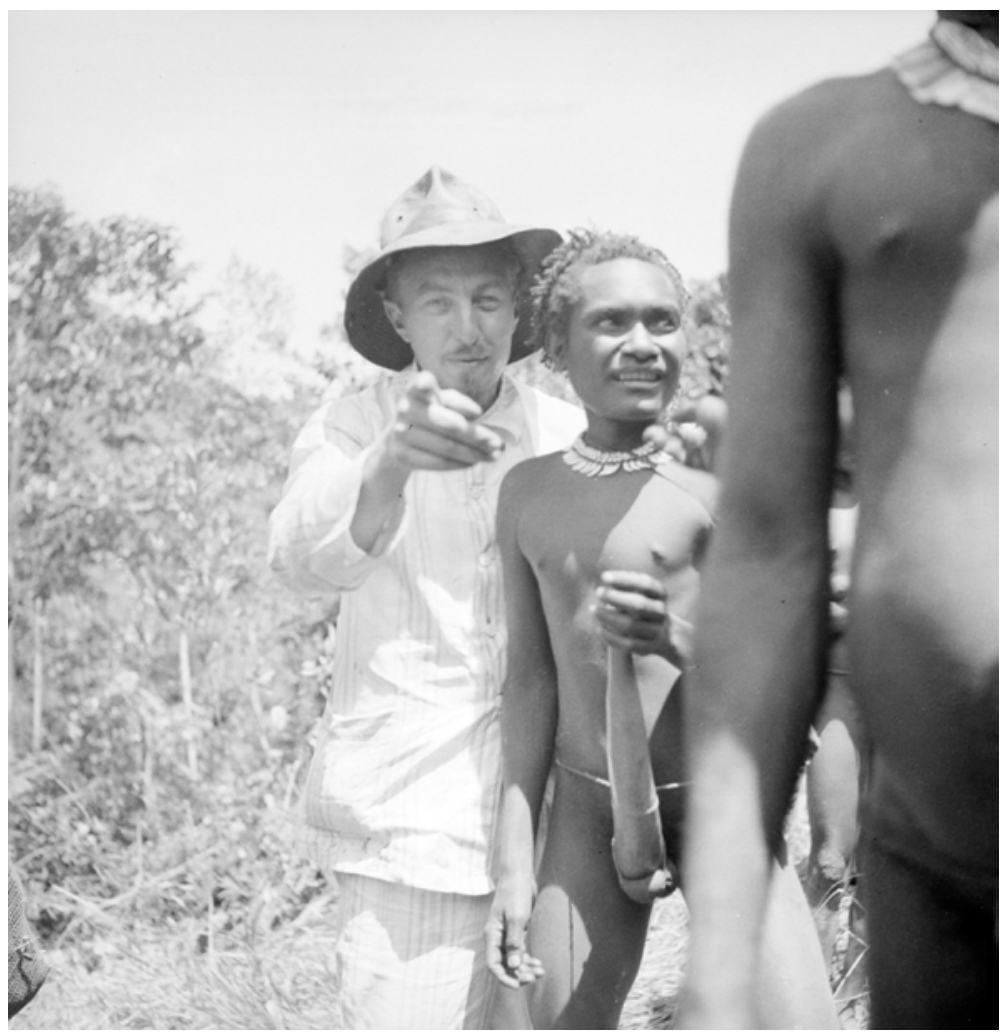

\section{Figure 2.3. Father Tillemans points out the presence of a camera to an Ekari Papuan, 1936.}

Source: Tropenmuseum Collection 10032916, http://papuacollectie.ab-c.nl.

In the decades following the period described in these snapshots, the idea that Papuans were living in the Stone-Age persisted. John F. Kennedy referred to the fact that the Papuans were 'living, as it were, in the Stone-Age' to justify the United State's refusal to intervene on behalf of their right to self-determination when the Dutch lobbied his administration to oppose the territory's transfer to Indonesia in 1962. Even today, Jared Diamond (2012) is still writing of West Papuans as a modern day version of 'non-metallic savages' who can tell us what the 'world until yesterday' looked like for the entire human race. This is not to mention the Stone-Age tribes, Stone-Age dogs, Stone-Age diets and StoneAge climbing gyms that a quick Google search turns up. It is hard to imagine another colonial conceit that has had such staying power. Only by attending to the power of paper - and the fraught encounters that left their traces in these texts - can we grasp how the Stone-Age gained its grip and came to have the implications the other essays in this volume describe so well. 
Essays are technology demonstrations, and while our status as their authors is fictive, our responsibilities are real. How should today's anthropologists of West Papua be mobilising paper's power? What should we make of our own deployment of all this machinery and the pleasures and anxieties it provokes? With what habits and passions should we be handling our words? Contending with the Stone-Age fantasy that has dogged West Papuans may be the right place to begin.

\section{References}

Austin, John Langshaw 1976. How to Do Things with Words. London: Oxford University Press.

Ballard, Chris, Vink, Steven and Ploeg, Anton 2002. Race to the Snow: Photography and the Exploration of Dutch New Guinea, 1907-1938. Leiden: KITLV Press.

Benveniste, Émile 1971. Problems in General Linguistics. Coral Gables (Florida): University of Miami Press.

Bhabha, Homi 1994. 'Of Mimicry and Man: The Ambivalence of Colonial Discourse'. In Bhabha, Homi (ed.), The Location of Culture. London: Routledge, 121-131.

Bijlmer, Dr. H.J.T. n.d. Naar de Achterhoek der Aarde. Amsterdam: Scheltens and Giltay.

Boelen, K.W.J. 1955.Dokter aan de Wisselmeren. Baarn: Bosch and Keuning N.V.

De Bruijn, Jan Victor 1939a. Verslag van een tocht naar Kemandora in Centraal Nieuw-Guinea door den Adspirant-Controleur der Wisselmeren Dr. J.V. de Bruijn van 20 Februari 1939 tot 10 Maart 1939. ARA Min van Kol. Kantor Bevolkingszaken Hollandia Rapportarchief 2.10.25, inv. 253.

De Bruijn, Jan Victor 1939b. Verslag van een tocht van Enarotali via Itodah, Janopa, Obaja, Kamere naar Orawja door den Adspirant-Controleur der Wisselmeren Dr. J.V. de Bruijn van 4 Mei 1939-14 Mei 1939. ARA 2.10.25, inv. 254.

De Bruijn, Jan Victor 1939c. Verslag van een tocht naar het brongebied van de Edere of Elegeboe-rivier in Centraal Nieuw Guinea door den Adspirant-Controleur der Wisselmeren Dr. J.V. de Bruijn van 29 Juli 1939 tot 7 Augustus 1939. ARA 2.10.25, inv. 255. 
From 'Stone-Age' to 'Real-Time'

De Bruijn, Jan Victor 1941. Verslag van een tocht naar Beura, het stroomgebied van de Beurong en Ielop, het stroomgebied van de Ielorong in Centraal Nieuw Guinea door den Controleur der Wisselmeren Dr. J.V. de Bruijn van 9 juni 1941 tot 7 augustus 1941. ARA 2.10.25, inv. 256.

Dening, Greg 1980. Islands and Beaches: Discourse on a Silent Land. Honolulu: University of Hawaii Press.

Derix, Jan 1987. Bapa Papoea; Jan P.K. van Eechoud, Een Biografie. Venlo: Van Spijk.

Derrida, Jacques 1982. 'Signature, Event, Context'. Trans. Weber, Samuel, Margins of Philosophy. Chicago: University of Chicago Press, 307-330.

Derrida, Jacques 1986. 'Declarations of Independence'. Trans. Keenan, Thomas and Pepper, T. New Political Science 15: 11.

Diamond, Jared 2012. The World Until Yesterday: What Can We Learn from Traditional Societies? New York: Viking.

Drooglever, Pieter J. 2005. Een Daad van Vrije Keuze: De Papoea's van Westelijk Nieuw-Guinea en de Grenzen van het Zelfbeschikkingsrecht. Instituut voor Nederlandse Geschiedenis. Amsterdam: Boom.

Gammage, Bill 1998. The Sky Travellers: Journeys in New Guinea 1938-1939. Melbourne: Melbourne University Press.

Giay, Benny 1995. Zacheus Pakage and His Communities: Indigenous Religious Discourse, Socio-Political Resistance, and Ethnohistory of the Me of Irian Jaya. PhD thesis, Free University, Amsterdam.

Goffman, Erving 1986 [1974]. Frame Analysis: An Essay on the Organization of Experience. Cambridge: Harvard University Press.

Haenen, Paul 1992. Weefsels van Wederkerigheid: Sociale Structuur bij de Moi van Irian Jaya. PhD thesis, University of Nijmegen.

Heidegger, Martin 1977. 'The Question Concerning Technology'. In Heidegger, Martin, The Question Concerning Technology and Other Essays. New York: Harper and Row, 3-35.

Hume, David 1988 [1748]. An Enquiry Concerning Human Understanding. Amherst: Prometheus Books.

Hutchins, Edwin 1995. Cognition in the Wild. Boston: MIT Press.

Lee, Benjamin 1997. Talking Heads: Language, Metalanguage and the Semiotics of Subjectivity. Durham: Duke University Press. 
Lubbock, John 1865. Pre-Historic Times, As Illustrated by Ancient Remains, and the Manners and Customs of Modern Savages. London and Edinburgh: Williams and Norgate.

Mauss, Marcel and Schlanger, Nathan (eds) 2006. Techniques, Technology, and Civilisation. Oxford: Berghahn Books.

Meijer Ranneft and Johan Everhard 1952. 'Memorie van Overgave van de Onderafdeling Wisselmeren, 1 November 1948 t/m 19 September 1952'. ARA 2.10.25, inv. 257.

Mueggler, Eric 2011. The Paper Road: Archive and Experience in the Botanical Exploration of West China and Tibet. Berkeley: University of California Press.

Mumford, Lewis 1967. Technics and Human Development. The Myth of the Machine Vol. 1. New York: Harvest Books.

Pospisil, Leopold 1963. The Kapauku Papuans of West New Guinea. New York: Rinehart and Wilson.

Riddington, Robin 1999. 'Dogs, Snares, and Cartridge Belts: The Poetics of a Northern Athapaskan Narrative Technology'. In Dobres, M.-A. and Hoffman, C.R. (eds), The Social Dynamics of Technology: Practice, Politics and World Views. Washington: Smithsonian Institution, 167-118.

Rutherford, Danilyn 2009. 'Sympathy, State-building, and the Experience of Empire'. Cultural Anthropology 24(1): 1-32.

Rutherford, Danilyn 2012. Laughing at Leviathan: Sovereignty and Audience in West Papua. Chicago: University of Chicago Press.

Spyer, Patricia 1998. "The Tooth of Time, or, Taking a Look at the "Look" of Clothing in Late Nineteen-Century Aru'. In Spyer, Patricia (ed.), Border Fetishisms: Objects in Unstable Places. London: Routledge, 150-182.

Stiegler, Bernard 1998. Technics and Time, I: The Fault of Epimetheus. Stanford: Stanford University Press.

Timmer, Jaap 2000. Living with Intricate Futures: Order and Confusion in Imyan Worlds, Irian Jaya, Indonesia. Nijmegen: Centre for Pacific and Asian Studies, University of Nijmegen.

Trouillot, Michel-Rolph 1991. 'Anthropology and the Savage Slot'. In Fox, Richard G. (ed.), Recapturing Anthropology: Working in the Present. Santa Fe: School for American Research Press, 17-44. 
van Eechoud, Jan Piet Karel 1938. 'Verslag van de Exploratie naar het Wisselmerengebied van 14 Mei - 14 November 1938 en Doorsteek van Paniai/Wisselmeer naar de Monding van de Siriwo van 15 November tot 1 December 1938. Onderleiding van J.P.K. van Eechoud, Commissaris van Politie 2e-Klasse'. ARA Min van Kol. Kantor Bevolkingszaken Hollandia Rapportarchief 2.10.25, inv. 246.

van Eechoud, Jan Piet Karel 1953. Met Kapmes en Kompas Door Nieuw-Guinea. Amsterdam: Uitgeverij van H.C. de Boer, Jr.

van Emmerik, E.M. 1953. 'Rapport over de Kapaukoe'. ARA 2.10.25, inv. 258.

Wollaston, Alexander Frederick Richmond 1912. Pygmies and Papuans: The Stone Age Today in Dutch New Guinea. London: Smith and Elder.

YouTube 2008. First Contact (Highlands Trilogy) - PREVIEW. http://www. youtube.com/watch?v=2Y5rC7kDx3o (accessed 23 August 2012). 
This text is taken from From 'Stone-Age' to 'Real-Time': Exploring Papuan Temporalities, Mobilities and Religiosities, edited by Martin Slama and Jenny Munro, published 2015 by ANU Press, The Australian National University, Canberra, Australia. 